Volume 12 | Issue 2

May 2021

\title{
Applying Crime Prevention and Health Promotion Frameworks to the Problem of High Incarceration Rates for Aboriginal and Torres Strait Islander Populations: Lessons from a Case Study from Victoria
}

\author{
Samantha Battams \\ Southgate Institute for Health, Society and Equity, Flinders University, Australia, samantha.battams@flinders.edu.au \\ Toni Delany-Crowe \\ Southgate Institute for Health, Society and Equity, Flinders University, Australia, toni.delanycrowe@flinders.edu.au \\ Matt Fisher \\ Southgate Institute for Health, Society and Equity, Flinders University, Australia, matt.fisher@flinders.edu.au \\ Lester Wright \\ Southgate Institute for Health, Society and Equity, Flinders University, Australia, lesw@att.net \\ Anthea Krieg \\ Ceduna Koonibba Aboriginal Health Service (Aboriginal Corporation), Australia, antheak@internode.on.net \\ Dennis McDermott \\ Director, Poche Centre for Indigenous Health, College of Medicine and Public Health, Flinders University, Australia \\ Fran Baum \\ Southgate Institute for Health, Society and Equity, Flinders University, Australia, fran.baum@flinders.edu.au
}

Recommended Citation

Battams, S., Delany-Crowe, T., Fisher, M., Wright, L., Krieg, A., McDermott, D., \& Baum, F. (2021). Applying crime prevention and health promotion frameworks to the problem of high incarceration rates for Aboriginal and Torres Strait Islander populations: Lessons from a case study from Victoria. The International Indigenous Policy Journal, 12(2). https://doi.org10.18584/iipj.2021.12.2.10208 


\title{
Applying Crime Prevention and Health Promotion Frameworks to the Problem of High Incarceration Rates for Aboriginal and Torres Strait Islander Populations: Lessons from a Case Study from Victoria
}

\author{
Abstract \\ This article examines what kinds of policy reforms are required to reduce incarceration rates of Aboriginal and \\ Torres Strait Islander people through a case study of policy in the Australian state of Victoria. This state provides a \\ good example of a jurisdiction with policies focused upon, and developed in partnership with, Aboriginal \\ communities in Victoria, but which despite this has steadily increasing incarceration rates of Indigenous people. \\ The case study consisted of a qualitative analysis of two key justice sector policies focused upon the Indigenous \\ community in Victoria and interviews with key justice sector staff. Case study results are analysed in terms of \\ primary, secondary, and tertiary crime prevention; the social determinants of Indigenous health; and recommended \\ actions from the Ottawa Charter for Health Promotion. Finally, recommendations are made for future justice \\ sector policies and approaches that may help to reduce the high levels of incarceration of Aboriginal and Torres \\ Strait Islander people.
}

\section{Keywords}

justice, crime prevention, health promotion, Aboriginal and Torres Strait Islander, The Ottawa Charter for Health Promotion

\section{Author Note}

Anthea Krieg is now at InComPro Aboriginal Association.

Dennis McDermott was Pro Vice-Chancellor (Indigenous) at La Trobe University prior to his passing.

\section{Acknowledgments}

We wish to dedicate this article to the memory of our late and esteemed colleague, Professor Dennis McDermott, who was committed to social justice and reducing the high incarcerations rates of Aboriginal and Torres Strait Islander people.

This article is based upon research funded by an Australian Research Council Grant (DP160100244).

\section{Creative Commons License} (c) (1) (3)

This work is licensed under a Creative Commons Attribution-Noncommercial-No Derivative Works 4.0 License. 
Battams et al.: Applying Crime Prevention and Health Promotion Frameworks

\section{Applying Crime Prevention and Health Promotion Frameworks to the Problem of High Incarceration Rates for Aboriginal and Torres Strait Islander Populations: Lessons from a Case Study from Victoria}

Aboriginal and Torres Strait Islander people in Australia ${ }^{1}$ experience significantly worse outcomes than non-Indigenous Australians on many measures of physical or mental health (Australian Government, 2020). These health inequities occur in parallel with similar inequities in rates of Aboriginal and Torres Strait Islander incarceration, compared with non-Indigenous counterparts (Australian Bureau of Statistics, 2018). Arguably, the root causes of both forms of inequity lie with the history and contemporary expressions of colonisation in Australia. Colonisation has disrupted the social, economic, and cultural bases of Aboriginal and Torres Strait Islander lives and health through introduction of infectious disease and an array of government-sanctioned processes including massacres, dispossession of lands and relocation, forced labour, removal of children, and enforced cultural assimilation (Carson et al., 2007; Sherwood, 2013). A contemporary result of these processes is that many Indigenous Australians are subject to social and economic disadvantages in areas such as income, employment, education, and housing (Carson et al., 2007). The processes of colonisation also continue to adversely affect Aboriginal and Torres Strait Islander people through systemic racism, trauma, loss of culture, and limited access to culturally safe and appropriate healthcare (Carson et al., 2007). Exposure to such conditions affects health via pathways such as stress, infectious disease, injury, poor diet, smoking, and alcohol use (Thomas et al., 2008).

Thus, the ongoing impacts of colonisation and resulting socioeconomic inequities are widely understood as social determinants of Indigenous health in Australia (Carson et al., 2007). Many of the same factors are understood to underlie high rates of Aboriginal and Torres Strait Islander incarceration, coupled with factors such as racist policing and harsh sentencing policies (Australian Law Reform Commission, 2017; Reeve \& Bradford, 2014). Thus, determinants of Indigenous incarceration can be seen as consistent with models of social determinants of health that highlight ways in which politics and power in contemporary hierarchical societies operate through mechanisms such as income and education to distribute resources and create inequalities in living conditions and health status (Solar \& Irwin, 2010).

Indigenous criminology has also emphasised the impacts of colonisation on contemporary justice experiences and analyses of Indigenous communities' contact with police and courts systems from a human rights and Indigenous perspective (Cunneen $\&$ Tauri, 2018). Such a perspective also recognises that experiences within the criminal justice system can themselves have negative impacts on health or determinants of health such as employment (Reeve \& Bradford, 2014). The strong interdependence between various areas of Aboriginal and Torres Strait Islander disadvantage, especially interaction with the criminal justice system, long-term health, and labour force outcomes highlights the need for holistic policy approaches (Reeve \& Bradford, 2014).

\footnotetext{
${ }^{1}$ In this article, we use Aboriginal and Torres Strait Islander or Indigenous Australians to refer to the First Peoples of Australia. When referring to Victoria government policies and programs examined in the article, we follow their practice of using "Aboriginal" or "Koori” to refer to the First Peoples of Victoria. Agreements and policies were frequently developed in partnership with the First Peoples of Victoria for all Aboriginal and Torres Strait Islander peoples living in Victoria. We use non-Indigenous to refer to Australians who are neither Aboriginal nor Torres Strait Islander.
} 
One crucial way in which governments can respond constructively to reduce health inequities is through holistic population-based social determinants of health approaches to health promotion and disease prevention. Such approaches, described in landmark documents such as the Ottawa Charter for Health Promotion (First International Conference on Health Promotion, 1986), hereafter the Ottawa Charter, eschew narrow, individualised strategies to modify health behaviours. Instead, these approaches focus on what can be done through policies in all sectors to cultivate healthy social and environmental conditions and build community health capabilities. Effective health promotion strategies can reduce premature disease and subsequent demand for expensive, remedial medical care. More recently, frameworks such as Health in All Policies have further developed and applied the notion of healthy public policy, as per the Ottawa Charter, informed by evidence on social determinants of health.

Health promotion advocates and practitioners have long recognised a need for primary, secondary, and tertiary approaches, aligned with frameworks such as the Ottawa Charter. Primary prevention focuses on promoting health, while secondary prevention focuses on preventing disease in the general population and in groups considered at higher risk. A tertiary approach focuses on promoting health and managing disease among those with existing chronic ill-health conditions. Primary, secondary, and tertiary strategies in health promotion have an established parallel with similar concepts in crime prevention (Baum, 2008, 2015; Baumann \& Ylinen, 2013).

Brantingham and Faust (1976) define primary crime prevention as focusing on the population at large and on modifying environments and strengthening community supports to stop crime before it is committed. Such initiatives may include promoting access to housing, employment, and education, which are also recognised as social determinants of health.

Secondary crime prevention focuses on individuals and communities considered at elevated risk of offending or victimisation, again in a similar way to secondary prevention in health. One form of secondary crime prevention is justice reinvestment, which aims to prevent crime and reduce imprisonment by redirecting public funding from prisons to programs to build individual and community resources in communities with higher incarceration rates (Evans, 2018; Tucker \& Cadora, 2003). Such initiatives have demonstrated positive benefits in some Indigenous communities in Australia (KPMG, 2018), but have tended to be seen as project-based trials rather than as a systematic strategy for reducing high incarceration rates.

Tertiary crime prevention focusses on those who have already offended or become victims of crime, to prevent reoffending or repeat victimisation (Baumann \& Ylinen, 2013). Many of the strategies recommended in a recent Australian Law Reform Commission Report (2017) on reducing incarceration of Aboriginal and Torres Strait Islander people were in this category, such as bail conditions, sentencing considering Aboriginality, community-based sentencing, prison programs and parole, and police accountability. They did not address determinants of incarceration or primary and secondary crime prevention. However, the report did highlight a need for trauma-informed and culturally appropriate rehabilitation services, consistent with calls for such services in the health sector (Dudgeon et al., 2014). As prisoners are more likely to have suffered trauma (Maschi et al., 2011), trauma-informed services should be a key part of tertiary crime prevention strategies. 
Any considerations of health promotion among Indigenous Australians should also recognise their holistic conceptions of health and wellbeing, which include deep connectedness with culture, spirituality, community, and country (Dudgeon et al., 2014). Alongside the negative determinants noted above, evidence on social determinants of Indigenous health also recognises the health benefits arising from these cultural connections, alongside other positive factors such as access to culturally safe healthcare, control over life circumstances, and self-determination (Dudgeon et al., 2014). Theses holistic conceptions of wellbeing and positive determinants of Indigenous health will also be relevant within a framework of primary, secondary, and tertiary crime prevention in Australia.

In this article, we explore how the Ottawa Charter principles for health promotion can offer insight into crime prevention strategies to reduce Indigenous incarceration in an Australian context. To do so, we examine Indigenous justice sector policies and action plans in one Australian state, Victoria, to consider the extent to which they focus on primary, secondary, and tertiary crime prevention and correspond with Ottawa Charter and Health in All Policies (Leppo et al., 2013) approaches. We selected Victoria because, among jurisdictions in Australia, it demonstrates a stronger commitment to the best practice of engaging with Indigenous communities to prevent crime and reduce incarceration of Aboriginal and Torres Strait Islander peoples in Victoria. Yet, even with this commitment, rates of incarceration are increasing.

\section{Literature Review}

\section{Victoria and Justice Sector Policy}

There are approximately 48,000 Aboriginal or Torres Strait Islander people living in Victoria, constituting around $0.8 \%$ of the population. The extreme minority status of the Indigenous population is more pronounced in south eastern Australia, where colonisation occurred earlier and more completely than in other parts of Australia and presents significant challenges for Indigenous Australians' ability to influence policy (Empowered Communities, 2015). There has been a long history of partnership between the Victorian justice sector and Aboriginal communities in Victoria, through successive Aboriginal Justice Agreements (Victorian Government, 2013, 2018a) and structures that have enabled a partnership approach. Table 1 tracks the range of policies relevant to the Aboriginal justice sector in Victoria, which has made this a unique jurisdiction in terms of its successive Aboriginal Justice Agreements since the Royal Commission into Aboriginal Deaths in Custody (Dodson et al., 1991). 
Table 1. Inquiries and Aboriginal Justice Inclusion Initiatives Relevant to the Victorian Justice Sector

\begin{tabular}{|c|c|c|}
\hline National \& state inquiries & Policy \& key programs & Structures \& roles \\
\hline $\begin{array}{l}\text { 1991 Royal Commission into } \\
\text { Aboriginal Deaths in Custody }\end{array}$ & $\begin{array}{l}\text { Koori Youth Justice Program } \\
(1992) \\
\text { Koori Courts }(2002) \\
\text { First Victorian Aboriginal Justice } \\
\text { Agreement (AJA1; 2000-2006) }\end{array}$ & $\begin{array}{l}\text { Victorian Aboriginal Justice } \\
\text { Advisory Committee (for first } \\
\text { AJA) }\end{array}$ \\
\hline $\begin{array}{l}1997 \text { National Ministerial } \\
\text { Summit on Indigenous Deaths } \\
\text { in Custody }\end{array}$ & $\begin{array}{l}\text { Second Victorian Aboriginal } \\
\text { Justice Agreement (AJA2; 2006- } \\
\text { 2012) }\end{array}$ & $\begin{array}{l}\text { Aboriginal Justice Forum (state- } \\
\text { wide; } 2000 \text {-current) }\end{array}$ \\
\hline $\begin{array}{l}2009 \text { Senate Legal and } \\
\text { Constitutional Affairs } \\
\text { Committee } \\
\text { Inquiry into Access to Justice }\end{array}$ & $\begin{array}{l}\text { Victorian Government } \\
\text { Aboriginal Inclusion Framework } \\
\text { (2011) }\end{array}$ & $\begin{array}{l}\text { Aboriginal Justice Caucus } \\
\text { (formerly Koori Caucus; state- } \\
\text { wide; 2001-current) }\end{array}$ \\
\hline $\begin{array}{l}\text { 2010-2011 Standing } \\
\text { Committee on Aboriginal and } \\
\text { Torres Strait Islander Affairs } \\
\text { Inquiry into the High Level of } \\
\text { Involvement of Indigenous } \\
\text { Juveniles and Young Adults in } \\
\text { the Criminal Justice System }\end{array}$ & $\begin{array}{l}\text { Mingu Gadhaba: Beginning } \\
\text { Together-Koori Inclusion } \\
\text { Action Plan (2012) }\end{array}$ & $\begin{array}{l}\text { Regional Aboriginal Justice } \\
\text { Advisory Committees (current) }\end{array}$ \\
\hline $\begin{array}{l}2012 \text { Protecting Victoria's } \\
\text { Vulnerable Children's Inquiry }\end{array}$ & $\begin{array}{l}\text { Koori Family Violence Court } \\
\text { Support Program (2012) } \\
\text { Koori Family Violence Police } \\
\text { Protocols (2012) }\end{array}$ & $\begin{array}{l}\text { Local Aboriginal Justice Action } \\
\text { Committees (current) }\end{array}$ \\
\hline $\begin{array}{l}2014 \text { Productivity } \\
\text { Commission Inquiry into } \\
\text { Access to Justice } \\
\text { Arrangements }\end{array}$ & $\begin{array}{l}\text { Victorian Aboriginal Justice } \\
\text { Agreement Phase } 3 \text { (AJA3; 2013- } \\
\text { 2018) }\end{array}$ & Koori Justice Unit (current) \\
\hline $\begin{array}{l}2015 \text { In the Child's Best } \\
\text { Interests. Systemic review of } \\
\text { the Victorian child protection } \\
\text { system's compliance with the } \\
\text { Aboriginal Child Placement } \\
\text { Principle in Victoria }\end{array}$ & $\begin{array}{l}\text { Burra Lotjpa Dunguludja } \\
\text { Victorian Aboriginal Justice } \\
\text { Agreement Phase } 4 \text { (2018) }\end{array}$ & Youth Justice Units (current) \\
\hline
\end{tabular}


Table 1. Inquiries and Aboriginal Justice Inclusion Initiatives Relevant to the Victorian Justice Sector (continued)

\begin{tabular}{|c|c|c|}
\hline National \& state inquiries & Policy \& key programs & Structures \& roles \\
\hline $\begin{array}{l}2016 \text { Always Was Always Will } \\
\text { Be Koori Children: Systemic } \\
\text { Inquiry into Services Provided } \\
\text { to Aboriginal Children and } \\
\text { Young People in Out-of- } \\
\text { Home Care in Victoria }\end{array}$ & $\begin{array}{l}\text { Yarrwul Loitjba Yapaneyepuk- } \\
\text { Walk the Talk Together Koori } \\
\text { Inclusion Action Plan (2017- } \\
2020)\end{array}$ & $\begin{array}{l}\text { Aboriginal Children's Forum } \\
\text { (current) \& Indigenous Family } \\
\text { Violence Partnership Forum } \\
\text { (current) }\end{array}$ \\
\hline $\begin{array}{l}2017 \text { Australian Law Reform } \\
\text { Commission, Pathways to } \\
\text { Justice-An Inquiry into the } \\
\text { Incarceration Rate of } \\
\text { Aboriginal and Torres Strait } \\
\text { Islander Peoples }\end{array}$ & $\begin{array}{l}\text { Wungurilwil Gapgapduir: } \\
\text { Aboriginal Children and Families } \\
\text { Agreement and Strategic Action } \\
\text { Plan } 2018\end{array}$ & $\begin{array}{l}\text { Commissioner for Aboriginal } \\
\text { Children and Young People } \\
\text { (2013) \& Special Adviser for } \\
\text { Aboriginal Self-Determination } \\
\text { (2018) \& Victorian Treaty } \\
\text { Advancement Commissioner } \\
\text { (2018) }\end{array}$ \\
\hline
\end{tabular}

During this study, the Victorian Aboriginal Justice Agreement (Victorian Government, 2013), hereafter AJA3, was in its third phase. The AJA3 was part of a broader suite of policies and initiatives supporting partnerships between Aboriginal communities and the justice sector (see Table 1), including the Victorian Government (2011) Aboriginal Inclusion Framework. This framework refers to how government departments do business with Aboriginal and Torres Strait Islander peoples in Victoria. Arising from this framework are Mingu Gadhaba: Beginning Together-Koori Inclusion Action Plan (Victorian Government, 2012) and its successor Yarrwul Loitjba Yapaneyepuk: Walk the Talk Together: Koori Inclusion Action Plan (Victorian Government, 2017), which are action plans described further below. A treaty was also being developed between the Government of Victoria and Aboriginal communities in Victoria through the First Peoples' Assembly of Victoria: In 2018, the government appointed a Special Adviser for Aboriginal Self-Determination and a Victorian Treaty Advancement Commissioner to progress a treaty.

\section{Growing Incarceration Rates}

Incarceration rates are rising in many countries, including the US (The Sentencing Project, 2019) and Australia (Australian Bureau of Statistics, 2019), whilst remaining steady or declining in some European countries (World Health Organization [WHO] Regional Office for Europe, 2019). The Australian imprisonment rate (which includes those in prisons and those detained in remand centres) has increased by 130\% since 1985 (Leigh, 2019). The 1991 Royal Commission into Aboriginal Deaths in Custody (Dodson et al., 1991) highlighted the high incarceration rates of Indigenous people and deaths in custody, and how these are linked to colonisation, social and economic disadvantage, and social control. Incarceration rates for Aboriginal and Torres Strait Islander people continue to be much higher 
than for other Australians (Australian Bureau of Statistics, 2019), are the highest in the world for a specific population group (Thalia, 2017), and are still increasing.

Victoria has rates of incarceration of Aboriginal and Torres Strait Islander people (2,266 per 100,000 population), which are slightly lower than that of Australia as a whole (2,492 per 100,000; Australian Bureau of Statistics, 2019). However, the rates of imprisonment of Aboriginal and Torres Strait Islander Victorians have increased significantly: from 1,013 to 2,015 per 100,000 between 2008 and 2018 (Australian Bureau of Statistics, 2018; Victorian Government, 2018a). Between 2011 to 2012 and 2016 to 2017, there was an increase of 52.6\% in the rate of Aboriginal and Torres Strait Islander people in Victoria under justice supervision (community corrections and prison), compared with a 34\% increase in the rate for non-Indigenous Victorians (State of Victoria, 2019).

\section{The National Policy Context}

Since 2008 the Australian Government has led a national Closing the Gap (CTG) strategy intended to eliminate or reduce inequalities between Indigenous and non-Indigenous Australians in health (life expectancy, child mortality), education (literacy and numeracy, school attendance and completion), and employment outcomes. However, inequalities persist in all these areas and CTG targets are generally not being met (Australian Government, 2020). Arguably, the limited progress of CTG policy can be understood as resulting from a lack of effective action on social determinants of Indigenous health (Mackean et al., 2019). High rates of incarceration also help to explain this lack of progress (Reeve \& Bradford, 2014).

In the justice sector, the Australian Law Reform Commission's (ALRC, 2017) Pathways to Justice: Inquiry into the Incarceration Rate of Aboriginal and Torres Strait Islander Peoples report called for greater government accountability and national criminal justice targets to reduce Indigenous incarceration. It also called for local justice reinvestment strategies in partnership with Indigenous Australian communities, community-based initiatives to reduce the harmful effects of alcohol, and changing laws so that fine default does not result in imprisonment.

The Royal Commission into the Protection and Detention of Children in the Northern Territory (Australian Government, 2017) found poor conditions within and mistreatment of youth in detention centres, who were primarily Aboriginal or Torres Strait Islander children. The detention centres did not meet the standards set out by international guidelines or UN child rights conventions.

Recommendations included improved government oversight, staff training, and a preventative public health approach to child health. This report highlighted the discrepancies across jurisdictions in Australia, and how Aboriginal justice sector voices (that do exist in Victoria through various structures and mechanisms) can help prevent such poor conditions.

Full implementation of the recommendations of the ALRC report and the Royal Commission has yet to occur. Access to justice and police accountability strategies identified by national and state inquiries also have not been fully implemented. 


\section{Methods}

The research was part of a broader project considering how the social determinants of health and wellbeing were addressed in the urban planning, environment, energy, and justice sectors (Baum et al. 2018). For the purposes of this larger project, the criminal justice sector was understood as the work of the Department of Justice and Attorney General functions, courts, policing, and corrections. The policy analysis involved a systematic procedure for collecting the appropriate policy documents, and reading, coding, synthesising, theming, and theorising about the data (Corbin \& Strauss, 2008; Liamputtong \& Ezzy, 2006). For the justice sector aspect of the project, all current, strategic policy, selected legislative documents, and the most recent annual report from all criminal justice sector departments in the nine Australian governments (all state and territory governments, and the federal government) were collected between March and September 2016. In total, 144 justice documents were collected. We considered the policies in terms of primary, secondary, and tertiary crime prevention, and created key terms associated with these categories, which we then used in our coding framework (see Table 2). The framework for primary, secondary, and tertiary crime prevention was based upon previous analyses of these levels of crime prevention (Brantingham \& Faust, 1976).

The coding of documents (policy and interviews) was carried out by two team members, with the analysis cross checked with all members of the team. The research project was approved by the Flinders University Social and Behavioural Research Ethics Committee (Project Number 7176).

The review of 144 justice sector policies across jurisdictions found little evidence of primary and secondary crime prevention or acknowledgement of the social determinants of health. However, Victoria emerged as the jurisdiction that most considered the social determinants within policy and which had most emphasis on upstream prevention, especially in relation to Indigenous incarceration. For this reason, Victoria was selected as a jurisdiction to explore further through a case study and, specifically, to examine justice sector policies that focused upon Aboriginal and Torres Strait Islander communities.

Two key policies were identified as setting the overarching principles, goals, and strategies for Victorian justice sector action on Indigenous crime prevention and reduced incarceration at the time of our research: The Aboriginal Justice Agreement Phase 3: A Partnership Between the Victorian Government and Koori Community (AJA3), and Mingu Gadhaba: Beginning Together-Koori Inclusion Action Plan (Mingu Gadhaba). Koori is an Indigenous term for Aboriginal people in Victoria. This article is thus based upon a qualitative analysis of these two policies. AJA3 was developed as an updated version of previous agreements. Mingu Gadhaba was developed to extend commitments in the Victorian Government Aboriginal Inclusion Framework into the justice sector. Aboriginal policy actors and community representatives in Victoria were involved in development of both policies. 
Table 2. Primary, Secondary, and Tertiary Crime Prevention

\begin{tabular}{|c|c|c|c|}
\hline & Primary crime prevention & Secondary crime prevention & Tertiary crime prevention \\
\hline Definition & $\begin{array}{l}\text { Stopping crime before it } \\
\text { occurs by addressing social } \\
\text { and situational factors that } \\
\text { may lead to crime. Strategies } \\
\text { for whole of population. }\end{array}$ & $\begin{array}{l}\text { Early intervention for } \\
\text { population groups seen to } \\
\text { be at high risk of or } \\
\text { overrepresented in crime in } \\
\text { order to prevent crime. }\end{array}$ & $\begin{array}{l}\text { Efforts to prevent reoffending } \\
\text { and divert people who have } \\
\text { committed crimes away from } \\
\text { imprisonment. }\end{array}$ \\
\hline $\begin{array}{l}\text { Examples policy } \\
\text { and practices } \\
\text { related to the } \\
\text { justice sector }\end{array}$ & $\begin{array}{l}\text { - Public safety campaigns } \\
\text { (e.g., addressing violence } \\
\text { against women and } \\
\text { children) } \\
\text { - Neighbourhood \& } \\
\text { environmental design } \\
\text { (e.g., Crime Prevention } \\
\text { Through Environmental } \\
\text { Design) } \\
\text { - Drug and alcohol } \\
\text { regulation, prevention } \\
\text { programs and services } \\
\text { - Public and social housing } \\
\text { investment } \\
\text { - Community-based } \\
\text { programs } \\
\text { - Truancy campaigns } \\
\text { - Neighbourhood Watch }\end{array}$ & $\begin{array}{l}\text { - Community-led responses } \\
\text { to crime } \\
\text { - Community-based } \\
\text { programs } \\
\text { - Youth justice initiatives } \\
\text { (e.g., crime prevention } \\
\text { camps) } \\
\text { - Community-engaged } \\
\text { policing } \\
\text { - Neighbourhood and } \\
\text { transport policing } \\
\text { - Early intervention } \\
\text { programs } \\
\text { - Justice reinvestment }\end{array}$ & $\begin{array}{l}\text { - Detentions, fines } \\
\text { - Youth courts } \\
\text { - Therapeutic jurisprudence } \\
\text { - Diversionary courts } \\
\text { - Conciliation conferencing } \\
\text { - Restorative justice } \\
\text { - Family conferencing } \\
\text { - Prison-based education and } \\
\text { employment programs } \\
\text { - Post-release programs } \\
\text { (e.g., education and } \\
\text { employment) } \\
\text { - Redistributive justice } \\
\text { - Suppression (e.g., cautions } \\
\text { from police) }\end{array}$ \\
\hline Key terms & $\begin{array}{l}\text { - Public safety campaigns } \\
\text { - Stop/stopping crime } \\
\text { - Training \& employment } \\
\text { - Poverty reduction } \\
\text { - Housing/accommodation } \\
\text { - Access to alcohol and other } \\
\text { drugs } \\
\text { - Community development } \\
\text { - Community \& school } \\
\text { policing } \\
\text { - Urban renewal } \\
\text { - Neighbourhood design } \\
\text { - Security measures }\end{array}$ & $\begin{array}{l}\text { - Community-based } \\
\text { responses } \\
\text { - Justice reinvestment } \\
\text { - Early intervention } \\
\text { - Developmental strategies } \\
\text { - Social development model } \\
\text { - Community policing } \\
\text { - Neighbourhoods and } \\
\text { populations at risk } \\
\text { - Indigenous community } \\
\text { justice initiatives }\end{array}$ & $\begin{array}{l}\text { - Recidivism } \\
\text { - Reunited/family } \\
\text { - } \text { reunification } \\
\text { - } \text { Reoffend/reoffending } \\
\text { - } \text { Diversion/diversionary } \\
\text { - Therapeutic approach } \\
\text { - Therapeutic jurisprudence } \\
\text { - Therapeutic justice } \\
\text { - Rehabilitation } \\
\text { - Pre-and post-release } \\
\text { - Restorative } \\
\text { - } \text { justice/conferencing } \\
\text { - } \text { Pamily conferencing } \\
\text { Procedural justice/fairness }\end{array}$ \\
\hline
\end{tabular}


AJA3 was the third justice agreement, a partnership between the Victorian government and Koori community of Victoria. The first agreement emerged immediately following the Royal Commission into Aboriginal Deaths in Custody (Dodson et al., 1991). The AJA3 aimed to improve Koori justice outcomes in the areas of crime prevention and early intervention, diversion and strengthening alternatives to imprisonment, reducing reoffending, reducing conflict, violence and victimisation, creating responsive and inclusive services, strengthening community justice responses, and improving community safety.

Mingu Gadhaba was the Victorian Department of Justice's Koori Inclusion Action Plan. It had four components: systemic inclusion; data and service improvement; Koori employment and economic participation; and communication, engagement, and partnerships. It included targets such as increasing employment of Koori in the justice sector and ensuring that Koori businesses and/or staff were represented in procurement. Mingu Gadhaba corresponds with the Victorian Government's Aboriginal Inclusion Framework.

In addition to analysis of these two key policies, we also considered policy developments since the period of interest to this study, including the Burra Lotjpa Dunguludja: Victorian Aboriginal Justice Agreement-Phase 4(AJA4), (Victorian Government, 2018a), and the successor to Mingu Gadhaba, Yarrwul Loitjba Yapaneyepuk (Victorian Government, 2017).

The policies were searched for keywords associated with the three levels of crime prevention, as shown in Table 2. In addition to applying our crime prevention framework, we mapped Victorian Indigenous justice sector policies against the strategies recommended in the Ottawa Charter for Health Promotion (WHO, 1986). The Ottawa Charter includes five areas of action: building healthy public policy, creating supportive environments, strengthening community actions, developing personal skills, and reorienting health services towards health promotion. Addressing social determinants of health is fundamental and cuts across all five areas. We applied these five action areas as a framework for our analysis of policy documents. In examining action to build healthy public policy, we took account of a Health in All Policies approach (Leppo et al., 2013), which emphasises the need for all policy sectors to contribute to health and wellbeing through policy and actions. This approach is also relevant to addressing the multiple forms of disadvantage facing Indigenous Australians (Reeve \& Bradford, 2014).

The aim of undertaking further analysis of these policies was to understand in greater depth the way in which this jurisdiction incorporated primary, secondary, and tertiary crime prevention, and the social determinants of Indigenous health within policies. It was also to understand why, despite having policies intended to reduce Aboriginal and Torres Strait Islander incarceration, rates have increased in recent years.

As part of the case study, interviews were also conducted with key Aboriginal staff in the justice sector in Victoria. The objective of the interviews was to get the perspectives of people within the Aboriginal justice sector who had been involved in policy processes related to Mingu Gadhaba and associated partnerships between the Victorian government and Aboriginal communities. All interviewees had close links with these communities. All potential interviewees were initially approached by email, through which they received information on the research and an invitation to participate with a consent form. A follow-up email or phone call was made two weeks later if no reply was received. All interviewees agreed 
to be interviewed via this process and signed a consent form. Interviews were conducted by phone and audio recorded. The recording was transcribed by a professional transcription service, de-identified, and stored securely on university servers.

Three interviews were conducted (in 2018) with the staff able to be contacted and available for interview; other staff members who participated in development of Mingu Gadhaba were unable to be contacted, despite several attempts to do so. Whilst the small number of interviews is a limitation for this aspect of our study, it is important to note that the team involved in policy development was quite small to begin with. Our interview participants were two Aboriginal people employed within the justice sector in Victoria in the Aboriginal policy area, and one person who worked for an Aboriginal Community Controlled Organisation and was involved in regional and local Aboriginal justice advisory committees and policy processes. The latter person provided a useful non-government perspective on incarceration rates and partnership arrangements in Victoria.

NVIVO software was used to organise and code data from both the policies and interviews separately. Interview transcripts were initially coded against our crime prevention framework (Table 2) and the five categories of health promotion action derived from the Ottawa Charter. Themes were drawn from the justice sector policies and triangulated with themes from data derived from the interviews and analysed in terms of the crime prevention framework utilised, the Ottawa Charter for Health Promotion, and a Health in All Policies approach.

\section{Results}

In this section, we present our results according to the frameworks selected for analysis described above.

\section{Ottawa Charter-Strengthening Community Action}

To enact the goal of strengthening community action, the Ottawa Charter calls for actions to engage communities in decision-making, vesting ownership and control in communities, and building community resources. There was a strong focus on partnerships between the Victorian justice sector and Aboriginal communities in Victoria, commencing with the establishment of the first AJA 20 years ago. Both AJA3 and Mingu Gadhaba refer to strengthening community action through partnerships. Partnerships were strengthened through the development and implementation of Mingu Gadhaba, with a range of support structures in place (see Diagram 1). These included the Aboriginal Justice Forum (state-wide), the Aboriginal Justice Caucus (state-wide), the Regional Aboriginal Justice Advisory Committees (RAJACs), the Local Aboriginal Justice Advisory Committees (LAJACs), and Koori Courts. Also relevant to the justice sector were the Aboriginal Children's Forum and Indigenous Family Violence Forum. In addition, the government's Koori Inclusion Unit is located within the Victorian Department of Justice to support implementation of policies. These various structures to support Aboriginal community engagement in justice sector policy are shown in Figure 1. 


\section{Figure 1. Structures to Support Aboriginal Community Engagement in Justice Sector Policy}

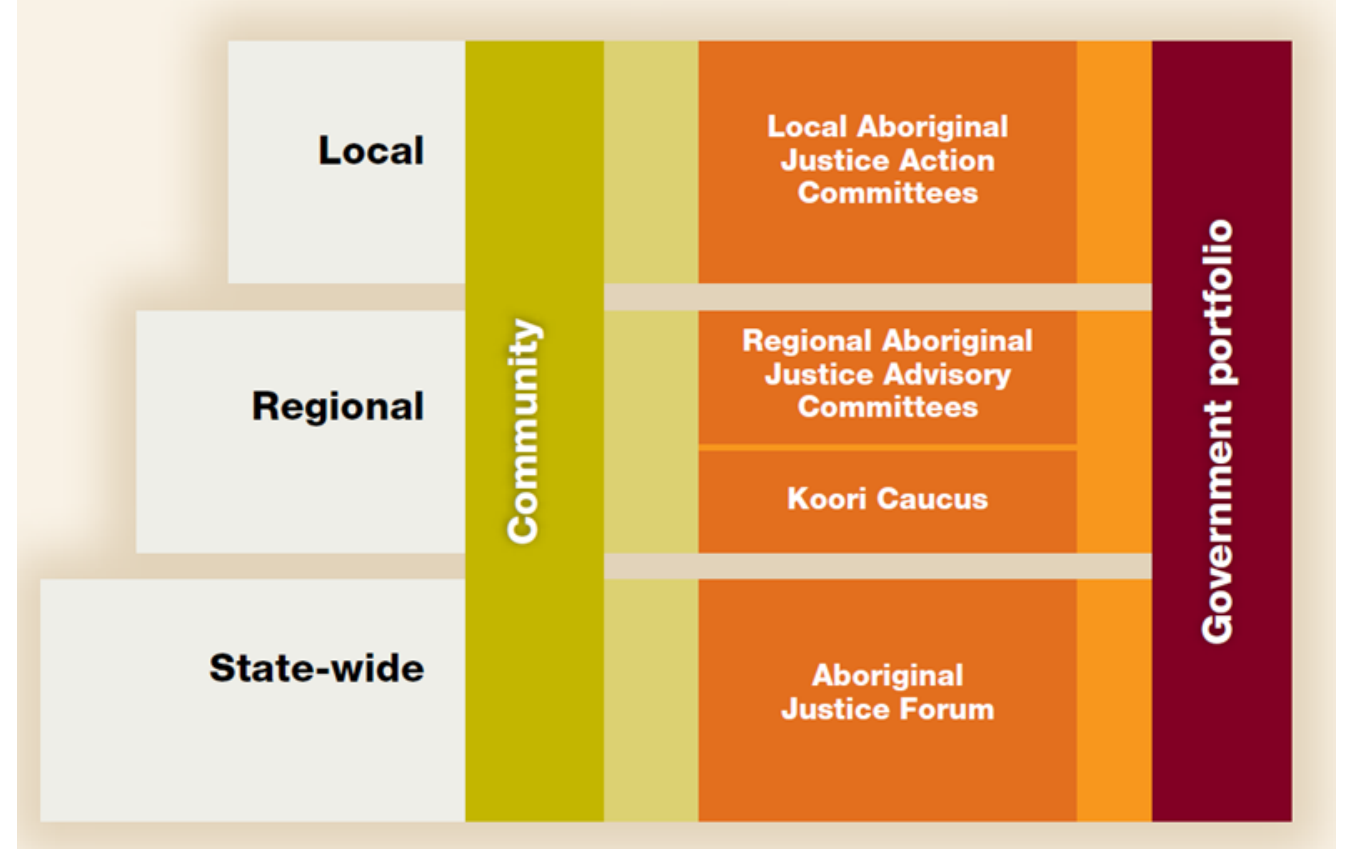

Note. From Victorian Aboriginal Justice Agreement Phase 3 (AJA3): A Partnership Between the Victorian Government and Koori Community, by Victorian Government, 2013, p. 66. Copyright 2013 by the Government of Victoria.

The interview participants in the study suggested that the partnerships between the Victorian government and Indigenous groups through the various structures noted above have enabled input into decision-making and implementation for Indigenous justice sector policies.

And over the years that network has grown to the point now where we have nine RAJAC [Regional Aboriginal Justice Advisory Committees] regions, we have a very, very powerful voice on that forum and throughout the State because we now have a Koori Justice, a very strong Koori Justice Unit. We also have a Koori Caucus, which is made up of the chairpersons of the RAJAC as well as the other peak body members that are on the forum. Membership is sort of, you apply for membership and then if the forum agrees to that then you become a member. So, we have all our Aboriginal peak bodies as members of the forum. (Interview 3, Aboriginal Community Controlled Organisation worker)

The Koori Courts were a part of the current justice system, enabling the input of Elders in the sentencing process. This was explained by one interviewee who emphasised that they were not about establishing a "separate" Aboriginal justice system.

At the start when we had Koori Courts, we had to be proactive in media engagement and trying to get the positive word out there around the fact that this wasn't creating an alternate system. That it is actually within the parameters of the sentencing legislation. That all that it was, was an 
ability for Aboriginal Elders and respected people to sit with the magistrate and think about what this person before them would need to stop them from their particular trajectory. That, essentially, the magistrate would still ... be confined to the legislation in terms of how he or she would make a decision based on sentencing. So, we ... were very clear about making sure that there wasn't this backlash from community about Aboriginal people having their own special or separate system ... The only difference is that we had Aboriginal voices embedded into the process. (Interview 1, Indigenous policy manager)

The partnerships that have developed between Aboriginal communities and government enabled greater participation in decision-making at a senior policy level when it came to justice initiatives that directly affected Aboriginal and Torres Strait Islander people. Mingu Gadhaba was also considered by interviewees to increase accountability to Aboriginal communities.

Q: So, you're saying that the Koori community members actually meet with ministers, so there's a level of formal accountability there, they can't sort of hide from decisions that may be made that are not in the best interests of Koori community members?

A: Yep. Exactly right, and if there's - what we're finding at the moment is that bail and legislation reforms ... will have, and will continue to impact on Aboriginal people as a disadvantaged group, but we're working to look at initiatives that might minimise that sort of contact, so we have support to do that through the Department, and through the government. (Interview 2, Indigenous policy director)

So we've kind of put that same accountability measures back on each of the departments to ensure that they are doing the right thing by us. (Interview 3, Aboriginal Community Controlled Organisation worker)

However, while there was community input into decision-making, one interviewee suggested that more extensive community control and empowerment in the way justice sector resources are used has not been achieved.

I mean, it's good that they can, community comes and talks to us about the things that are impacting on them ... we'll know we're successful when community has full control over the resources and decision-making in terms of outcomes for the community. (Interview 2, Indigenous policy director)

\section{Ottawa Charter-Healthy Public Policy}

The Charter calls for putting "health on the agenda of policy makers in all sectors" and for them to accept responsibility for the health consequences of their decisions (First International Conference on Health Promotion, 1986, Build Healthy Public Policy section, para. 1), which is strongly consistent with Health in All Policies approaches. A whole of government, intersectoral approach was found within AJA3, sitting under the broader Victorian Aboriginal Affairs Framework 2013-2018 (Government of Victoria, 2018b), which supported the development of partnerships between justice and other sectors: 
As the Aboriginal Justice Agreement enters its third phase, the partnership is focused on improving justice outcomes by building stronger families and safer communities.

Work to improve education outcomes, enhance opportunities for employment and strengthen our economy has direct and positive impacts on reducing youth offending, lowering imprisonment rates and tackling family violence.

This work is supported by every area of government ...

Improved service coordination for at-risk Koori youth and families across the justice, welfare, health, and education sectors is also a priority. Closer collaboration between frontline workers is promoted across these areas, supported by integrated cross-sectoral approaches to prevention and early intervention. (Victorian Government, 2013, p. 3, p. 86)

The Aboriginal Justice Forum included representatives from a range of sectors and provided a space to discuss and address problems related to the justice sector. Furthermore, the Koori Inclusion Unit has prioritised the formation of relationships across sectors. Other sectors were approaching the justice sector staff to develop policies and strategies for Aboriginal people (e.g., education, child protection). The AJA3 was seen to be the basis of an inclusive approach taken towards Aboriginal people in Victoria, across government (by Aboriginal people employed by government, who had contact with a wide range of Aboriginal and non-Indigenous stakeholders).

Interviewees welcomed this cross-sectoral approach but noted a need to retain focus on key justice sector issues.

Through the Justice Agreement [AJA3], we have a very strong cross-government relationship with health, human services, police, courts, and all of those sorts of things ... With the previous Aboriginal Justice Agreements, we were kind of like the be all and end all, because there were no other appropriate strategies across the other departments that influence on justice outcomes, but in the last five years, we've now got a really excellent education strategy, we've got one in health and human services, we're starting one in forensic mental health, and the Justice Agreement. (Interview 2, Indigenous policy director)

We have had, through the [Aboriginal] Justice Forums, the engagement of [the Department of] Education, of DHHS [Department of Health and Human Services], of all the Aboriginal organisations that also run in that more proactive strength-based space. (Interview 1, Indigenous policy manager)

We've recently just gone through a review of the AJA3 and as a part of that there's been some concerns raised about losing sight of, or losing focus on, the justice issues itself because we deal with a lot of issues around DHHS and other areas where other agencies have responsibility. So, there was sort of like a push to perhaps reduce the [Aboriginal Justice] Caucus and the [Aboriginal Justice] Forum just to so that we can start to get back to dealing with core justice issues. (Interview 3, Aboriginal Community Controlled Organisation worker) 
Mingu Gadhaba — and its successor Yarrwul Loitjba Yapaneyepuk—were described in interviews as policies to ensure that business units of the Department of Justice were geared towards inclusiveness and outcomes for Aboriginal people in Victoria (e.g., in staff employment, procurement practices, consultation and representation policies, responsiveness towards clients). The process by which Mingu Gadhaba was developed, and the partnership structures put in place, also ensured that justice sector business units were accountable for their objectives.

There will be an increased Koori uptake of support services such as Consumer Affairs Victoria, Dispute Settlement Centre, Victims Services, Family Violence Courts Division, and Courts Integrated Service Program. (Victorian Government, 2012, p. 15)

Mingu Gadhaba ... is very much about looking at responsibility being sat in all other parts of the Department... It asks the questions, you know, "When you are looking at procurement practices within the line, the branch, within [the Department of] Justice, how aware are the procurement officers? How are considerations around ... support of Koori businesses embedded within their procurement policies?" ..."Where is your particular lens to supporting and encouraging Aboriginal participation in your business unit practices?” (Interview 2, Indigenous policy director)

\section{Ottawa Charter-Creating Supportive Environments}

Here the Charter recognises "inextricable links between people and their environments" as the basis for a social-ecological approach to health (First International Conference on Health Promotion, 1986, Create Supportive Environments section, para. 1), which is consistent with addressing social determinants of Indigenous health. Here our analysis showed that one of the principles of the AJA3 was acknowledgement that "the impact of dispossession of traditional lands, languages and cultures, as well as past policies including the separation of children from families, continues to affect Koori communities today" (Victorian Government, 2013, p. 63). Mingu Gadhaba was seen by interviewees to be part of an overall commitment to Aboriginal and Torres Strait Islander self-determination in Victoria. The proposed Victorian treaty was seen as an important step in self-determination for the Aboriginal communities in Victoria.

Our government here has just recently passed its legislation in looking at a treaty here in Victoria, that passed a couple of weeks ago in Parliament and providing of course the Labor Government gets back in, and also the notion of self-determination, which is what the government's policy wants to be. And there's been a lot of consultation around that. In fact, they've got an Aboriginal person employed just to look at that. (Interview 3, Aboriginal Community Controlled Organisation worker)

Well, the Victorian Government has given a commitment to Victorian Aboriginal people to not only engage in conversations about self-determination, but also about treaty. So, we have a Victorian Treaty Commissioner at the moment who's doing the scoping work around what a representative body would look like, and treaty not just for land, but for everything: economics, you know, the whole lot. So, our department and many other departments have been looking at, "What does self-determination mean in the community, and in the department?" And it means government having to hand over control and resources; I know that sounds huge, but hand over 
decision-making — but it's the real participation in decision-making. (Interview 2, Indigenous policy director)

Although recognition of the impacts of colonisation and commitment to treaty and self-determination are significant, there was little evidence of other justice sector action to create supportive environments in the policy documents analysed.

\section{Ottawa Charter-Developing Personal Skills}

The Charter calls for actions to "support personal and social development" through information, education, and life skills (WHO, 1986, Develop Personal Skills section, para. 1). Part of AJA3, the Koori Community Safety Grants Program led to community-based violence prevention activities aimed at developing education and skills designed to prevent violence. Therapeutic and skills-based programs were also delivered to Aboriginal people who had committed crimes. Empowerment was also evident in cultural strengthening programs for Koori men and women in custody or on community orders (AJA3). There was also evidence of support for Koori people in developing personal skills through the AJA3's Koori Cognitive Skills program, which focused on assisting people (in prisons and under community orders) to develop problem solving skills to deal with everyday problems.

\section{Ottawa Charter-Reorient Services}

The Charter calls for actions to reorient health services away from purely clinical and curative care towards a health promotion approach. In this research, Mingu Gadhaba is a policy that seeks to reorient justice sector practices in general toward a partnership approach with Victorian Aboriginal communities. There was also evidence of reorienting services through the AJA3's focus on frontline programs that "encourage youth to build positive and healthy lives, through leadership, sport, arts, education, training and community development" (Victorian Government, 2013, p. 40). This could also be considered an example of a "settings" approach.

\section{Primary Crime Prevention}

The AJA3 had a strong focus on crime prevention and early intervention to prevent and reduce contact with the justice system for youth, as well as to prevent recidivism:

AJA3 maintains an emphasis on prevention, early intervention and diversion to reduce further progression into the justice system. (Victorian Government, 2013, p. 15)

A key strategic focus of the AJA has been to prevent young Koories from coming into negative contact with the justice system, or if already there, to divert them from more serious contact. The other key focus has been to reduce reoffending and recidivism by those already in contact with the justice system. (Victorian Government, 2013, p. 27)

The third AJA included the following key initiatives for increasing crime prevention and early intervention and reducing reoffending: 
- Frontline Youth Initiatives and Community Initiatives Programs (a range of funded community-based youth initiatives).

- Koori Early School Leaver Program and Youth Employment Service (diverting Koori adolescents away from the justice sector by encouraging engagement in education and employment). (Attorney-General's Department, 2013; Victorian Government, 2013)

Another primary crime prevention aim was to reduce community violence and conflict in Aboriginal and Torres Strait Islander communities.

AJA3 will focus heavily on reducing conflict and violence across our community to improve community safety. We will only achieve this through collaboration and strong partnerships with and between all stakeholders. (Victorian Government, 2013, p. 4)

Despite this focus on primary prevention, unmet needs related to primary crime prevention were discussed by interviewees. These included the need for justice sector strategies that addressed Aboriginal and Torres Strait Islander people's needs in areas such as mental health, alcohol, and other drug support and rehabilitation; the need to protect vulnerable children and support parents and families; and more culturally responsive services for children in care. There is scope for the health promotion sector to play a greater role in all such activities.

\section{Secondary Crime Prevention}

Within AJA3, a strong focus for secondary crime prevention was youth justice (e.g., Koori Youth Cautioning Program) and community development programs (which were largely project based), violence prevention programs in high-risk communities (funded through community-based grant programs), and the employment of 100 Police Aboriginal Liaison Officers and 9 Aboriginal Community Liaison Officers to work with Aboriginal and Torres Strait Islander people. An example of these initiatives is below.

As part of the Victorian Government's Reducing Violence against Women and their Children Grants Program, a \$2.4 million Koori Community Safety Grants Program is supporting several intensive community-based projects that aim to address the high level of violence in Koori communities. (Victorian Government, 2013, p. 4)

A deliberate effort has been made in Victoria by the Koori Inclusion Unit (within the Department of Justice) to focus on community strengths and avoid replicating a focus on deficits through policy and strategies, and this is considered to have strengthened community engagement.

Our community told us we have to approach all the work that we do in a strength-based approach. So, we know that the situation isn't fantastic for our mob, but not everyone's involved in the criminal justice system. And that was important for us to recognise that, and build on opportunities where we can strengthen the community's capacity and also obviously our own to work on policies, and programs, and procedures, and all sorts of things. (Interview 2, Indigenous policy director) 
However, this strengths-based approach did not translate to a strong focus on ongoing primary and secondary prevention. As outlined earlier, justice reinvestment strategies are part of secondary prevention and ideally direct funding to social and physical infrastructure in communities with high incarceration rates. There were no justice reinvestment strategies referred to in the Victorian policies, and there is scope for such strategies to be funded in Aboriginal communities overrepresented in the justice system. However, these strategies should be approached with caution as they have been developed and implemented in very different ways across jurisdictions. They can also obscure the reality that a significant proportion of government funding is being channelled into building prisons, rather than addressing drivers of incarcerations (such as homelessness and lack of spending on public housing) (Millar \& Vedelago, 2019) and investing in community-led primary and secondary crime prevention responses.

\section{Tertiary Crime Prevention}

Our analysis of the policies showed that a strong focus on tertiary crime prevention was evident within AJA3, with specific reference to roles for diversionary approaches for youth and Koori women, and rehabilitation programs for prisoners. Strategies included Aboriginal-specific cultural strengthening programs, restorative justice, court liaison programs, and Koori Courts and Liaison Officers. The AJA3 included the following tertiary crime prevention initiatives:

- Aboriginal Cultural Immersion Program (a program that enables Aboriginal prisoners and people who had committed crimes to develop greater awareness and understanding of their cultural identity).

- Koori Cognitive Skills Program (a cognitive skills program adapted for Koori people who had committed crime designed to prepare and motivate them for participation in moderate or higher intensity, targeted, and offence-specific interventions).

- Koori KONNECT transition and post-release support program (tailored cultural planning and mentoring programs).

- Aboriginal Local Justice Workers and Koori Offender Support and Mentoring Program (a program that ensures Koori Elders provide community-based local support, advice, and cultural connection to people who had committed crime, as well as supervise them undertaking mandated community work in culturally appropriate worksites; AttorneyGeneral's Department, 2013; Victorian Government, 2013).

Some examples of tertiary crime prevention initiatives within AJA3 (Victorian Government, 2013) are:

Utilise Koori Liaison Officers to ensure access and uptake by Koories of Courts Integrated Service Program, and strengthen linkages between the program and Koori Courts at La Trobe Valley. (p. 101)

Ensure Courts Integrated Service Program brokerage models connect Koories on bail to services that address underlying drivers of offending, including alcohol and drug abuse and mental health 
concerns, including services delivered through Aboriginal community controlled organisations. (p. 101)

The Local Justice Worker Program and the Koori Offender Support and Mentoring Program, which have already proven effective in helping Koories to address fine payments, successfully complete community based orders, and reduce breach rates. (p. 29)

The problems of unstable housing, homelessness, unemployment, and their impact upon reoffending were well articulated in AJA3. Whilst there was strong recognition of problems such as the shortage of affordable housing, housing instability, and unemployment, strategies to address these issues appeared to be limited or developmental.

Consider ways to improve access to post release housing for Koori women, including opportunities for increasing planned exits and brokerage funding to explore long-term social housing, private rental and supported housing options. (Victorian Government, 2013, p. 118)

Establish an Indigenous Homelessness Working Group. This group will include Department of Justice representation and will be responsible for: identifying evidence-based housing and support models that assist Koori men and women exiting prison to make a successful transition to long term housing and reduce recidivism. (p. 117)

Given the focus of Mingu Gadhaba was inclusiveness of Aboriginal and Torres Strait Islander communities within the justice sector, it is not surprising that its impact was largely discussed in terms of tertiary crime prevention: Aboriginal-specific justice initiatives, routine notification of Aboriginal or Torres Strait Islander deaths in custody, justice sector staff's cultural awareness and perceptions of Aboriginal and Torres Strait Islander people, taking a systems approach to problems experienced in the justice sector, and developing Aboriginal and Torres Strait Islander communities members' trust and engagement in government offices and staff. The policy and associated processes also enabled a focus on procedural fairness and increased access to complaints mechanisms in the justice sector.

We've got our Koori Court systems, that's working well. Both the Magistrates and the Children's Koori Courts are working well because of the supports that are put in place. Rather than putting our mob in prison they get support through AOD services or other services that they may require. (Interview 3, Aboriginal Community Controlled Organisation worker)

There were several unmet needs related to tertiary crime prevention identified by interviewees. These included justice sector strategies that addressed mental health for Aboriginal and Torres Strait Islander people who had committed crimes, alcohol and other drug support and rehabilitation tailored for Aboriginal and Torres Strait Islander people, and long stays in remand-linked to alcohol and other drug problems and absence of accommodation options (especially for Aboriginal or Torres Strait Islander women and children). Unmet needs that still required addressing also included bail and legislative reform, more Aboriginal and Torres Strait Islander control over boards and resources, raising the age at which children could be remanded in Australia (currently 10 years of age), rehabilitation not providing adequate ongoing employment opportunities, negative public perceptions of Aboriginal and Torres Strait Islander-specific strategies, and breaking the nexus between child protection and youth justice. Ideas for policy strategies for the future included prisons and out-of-home care run by Aboriginal 
controlled organisations, strategies for families and children to maintain connection to culture, and the spread of Koori Courts.

\section{Discussion}

Our application of a crime prevention framework and the Ottawa Charter framework highlights the extent to which there has been a lack of focus on primary and secondary crime prevention strategies (and their evaluation), and the extent to which even progressive recommendations (such as those of the ALRC) that do focus on Indigenous people are stuck on tertiary approaches. Applying these frameworks also suggests participation by Indigenous people in the justice sector being an end in itself is insufficient and should rather be one vehicle to help address the underlying social determinants of high incarcerations rates of Aboriginal and Torres Strait Islander peoples. Our broader research on justice sector policies indicated that Victoria had the most progressive policies and partnership approaches; yet despite this, Victoria has continued high and growing incarceration rates for Aboriginal and Torres Strait Islander people.

This article has discussed some of the positive developments in the justice field in Victoria for Aboriginal and Torres Islander peoples. Reducing socio-economic inequities and incarceration rates among this group is vital if their health status, as a whole population, is to improve. As highlighted by Reeve and Bradford (2014) and Cunneen and Tauri (2018), the multiple areas of disadvantage for Aboriginal and Torres Strait Islander people work together in complex ways and require holistic solutions. There are multiple, contributing factors explaining the increased rate of incarceration: rising inequity; reduction in public spending on health, housing, and education; a strong focus on tertiary crime prevention within Victorian justice sector policy; public and political discourses on being "tough on crime;" and the ongoing effects of colonisation. Rising inequities and incarceration rates will further impact other indicators of disadvantage (Reeve \& Bradford, 2014). While tough-on-crime advocates may suppose that harsher sentencing policies will discourage crime, in fact they tend to increase rates of imprisonment, thus requiring extra public funds to expand capacity (Brown, 2010). A shift toward primary and secondary crime prevention is essential to escape the damaging consequences of tough-oncrime politics, but is difficult when the issue is politicised, as has been the case in Victoria in recent years (Alcorn, 2018).

Evidence shows that spending on prisons in Victoria increased by $90 \%$ between 2011 and 2018, whilst growth for public hospitals was $48 \%$, school education $25 \%$, and social and public housing just $1 \%$ (Millar \& Vedelago, 2019). Miller and Vedalgo (2019) argued that this disproportionate increase in prison spending is an outcome of tough-on-crime policies. In a recent budget, Victoria announced that it would spend \$1.8 billion on upgrading existing prisons in 2019 (Oxley, 2019).

There is a specific need to modify these tough-on-crime discourses, and shift effort and resources to a prevention approach if incarceration rates are to be reduced. Politicians in Australia have argued that being tough on crime is the desire of the public, but this approach is not part of evidence-based leadership and, in Australia, incarceration rates have increased with higher prison spending (Knaus, 2017). In addition, being tough on crime may not be directly linked to the desires and understandings of the public. A recent American poll indicated that communities in the USA do not believe that more jails and incarceration lead to lower crime rates (Greenberg Quinlan Rosner Research, 2018). 


\section{WHO Ottawa Charter for Health Promotion}

When it comes to the justice sector and Aboriginal and Torres Strait Islander communities in Victoria, there were areas where the jurisdiction was in accord with the Ottawa Charter. Through policies and partnerships, engagement was deepened between the justice sector and Aboriginal communities. The justice sector even appeared to be a vehicle for much intersectoral collaboration. However, overall, there was still a large focus on housing, education, employment support for ex-prisoners, and diversionary activities (i.e., tertiary crime prevention), with little evidence for "reorienting" justice sector activity towards secondary or primary crime prevention. Intersectoral strategies with the potential to address social determinants of crime and incarceration among Indigenous people lacked specificity and accountability mechanisms. In addition, much of the current activity is transitional or short-term support relying on the private sector (e.g., housing subsidies).

However, there is some evidence that justice reinvestment strategies, part of secondary crime prevention, have reduced crime rates in Aboriginal and Torres Strait Islander communities (Finizio, 2018). Currently, in Australia, there is a low political and funding commitment to justice reinvestment initiatives, and such initiatives are not routinely featured as a key element in Australian policies, but tend to be project based (Evans, 2018). Additionally, there is greater scope for the health promotion sector to be involved in justice reinvestment activities, given that community development skills and partnership approaches (essential to health promotion) are a key part of this approach.

There was some evidence that a Health in All Policies approach (Leppo et al., 2013) was being taken in the justice sector in Victoria, with key sectors such as the health, child wellbeing and protection, housing, and justice sectors working together-as recommended by Reeve and Bradford (2014). However, more whole-of-government accountability mechanisms are required. Additionally, greater investment in primary crime prevention and primary prevention in health is still necessary, including greater investment in child wellbeing and prevention of out-of-home care (Davis, 2019). In addition, many of the good secondary prevention initiatives in Victoria were tied to short-term grants and were project based. There is more scope for whole-of-government activity involving the justice sector that addresses the underlying causes of socioeconomic inequalities, and for a focus on areas of disadvantage with relatively large Aboriginal and Torres Strait Islander populations.

There are several policy areas that emerged from our study where more effective action across sectors would be beneficial:

- Co-ordination between justice, mental health, and housing services to ensure that people with mental health problems exiting the justice system have secure housing and do not end up homeless.

- Coordination between justice, child protection, domestic violence, and alcohol and other drugs services to break the nexus between Aboriginal or Torres Strait Islander children in out of home care and Aboriginal or Torres Strait Islander adults in the justice sector. Strategies might include tailored support for Aboriginal or Torres Strait Islander parents (e.g., home visiting programs) and domestic violence or drug and alcohol programs. Early intervention and prevention of contact with the child protection system and provision of 
culturally appropriate support for kids in out-of-home care (if required) is also necessary (see Davis, 2019).

- Coordination between justice and employment sectors to deliver early-intervention employment programs for Aboriginal or Torres Strait Islander youth, and longer-term employment programs for ex-prisoners. Links with housing programs are also required to help maintain people in employment.

- All sectors should address racism through cultural competence and cultural responsiveness training.

- Trauma-informed policy and practices.

\section{Primary, Secondary, and Tertiary Crime Prevention and the Health Sector}

There is evidence that primary health, or primary prevention activities can prevent or reduce crime. For example, there is some evidence for intensive early childhood education programs preventing crime (García et al., 2019; Temple \& Reynolds, 2007) and parenting programs delivered in supportive organisations and structures reducing child abuse and neglect (Shapiro et al., 2011). Domestic and family violence prevention education and peer strategies to reduce violence are also effective (Ellsberg et al., 2015). Investment in and diversion to community mental health (Evans et al., 2006) and alcohol and other drug programs (Bondurant et al., 2016) have also been linked to a reduction in crime. Whilst the health promotion sector is involved in many such initiatives, it is unclear how many of these strategies are tailored for Aboriginal and Torres Strait Islanders or involve the justice sector. Interviewees in this study emphasised the need for more culturally tailored prevention and rehabilitation activities. Integrated systems for youth with mental health issues and at risk of offending are also required (Evans et al., 2006). Strategies should be ongoing programs rather than being tied to grants and project based.

Many of the tertiary crime prevention strategies suggested by the ALRC (2017) are already in place in Victoria, but there was scope to expand these (for example, with respect to Koori Courts and Aboriginalspecific rehabilitation programs). In addition, utilising the expertise of the health promotion sector in community development could be beneficial for justice reinvestment initiatives (which were not funded or referred to in Victorian policy).

\section{International Relevance of this Research}

The Victorian case has greater applicability beyond the state of Victoria and has lessons for other countries, particularly when it comes to the development of partnership structures whereby public services and Indigenous communities can engage more effectively. Employment within the justice sector could be increased and justice sector procurement from Aboriginal and Torres Strait Islander businesses encouraged (the aims of Mingu Gadhaba and its successor). Addressing Aboriginal and Torres Strait Islander people's access to culturally relevant and safe services, along with increasing opportunities in areas such as child wellbeing, education, small business development, community development, culture and language, youth leadership programs, and care for country programs are required. Such strategies can address the social determinants of Indigenous health and wellbeing, applying a strengths-based approach. Well planned approaches to reconciliation and programs to reduce racism within organisations and the broader community would likely augment the success of strengths-based strategies. The Victorian Government Aboriginal Inclusion Framework (Victorian Government, 2011; 
described earlier) does provide a platform for such activity across government and is a good example that other countries could adopt.

Globally, WHO engagement with the justice sector appears to be largely focused on tertiary prevention rather than a health promotion approach. The WHO stated that prison health should be a key part of the public health system (WHO Regional Office for Europe, 2003), and a key report on adolescents recommends that the health sector collaborate with the justice sector for adolescent health (WHO, 2014). As recommended by the $\mathrm{WHO}$, health ministries should be accountable for prison health, and health services provided to prisons should be independent of justice sector administration (United Nations Office of Drugs and Crime [UNODC] and WHO Europe, 2013). The WHO highlights that overcrowding and poor conditions within prisons along with inattention to health concerns of prisoners may lead to infectious diseases (and mental illness) in prisons and result in wider public health concerns. A strategic and collaborative approach to the provision of health services (including mental health services) to those in the justice sector-in alignment with WHO recommendations - is necessary, along with a greater focus on primary prevention.

\section{Other Key Issues Emerging from the Research}

Despite over 40 years of policy initiatives to address disadvantage and incarceration rates among Aboriginal and Torres Strait Islander people, little progress has been made. Failure to make progress in Indigenous affairs can be seen not simply as a failure of (holistic) policy, but also a failure to evaluate implementation, knowledge exchange, practice tools, and frameworks to determine what works in practice; too often key performance indicators are measured against overall policy without such complex evaluation occurring (Moran, 2016). Moran (2016) has argued that policy reforms should consider past failures to inform the future and critiques a lack of policy and research focus on practice, calling for a greater focus on the evaluation of practice.

There are examples where tertiary crime prevention initiatives have been evaluated (e.g., drug treatment courts). However, the failure to address pressing issues such as housing, and family and child wellbeing outcomes (Boles et al., 2007; Wittouck et al., 2013), or access and transport issues for Aboriginal and Torres Strait Islander people (Rsavy et al., 2011) has created issues for the success of initiatives. Systematic reviews have shown that drug treatment courts lead to a reduction in general recidivism (general offending and convictions) and drug related recidivism (convictions on drug related charges) (Mitchell et al., 2012; Shaffer, 2011). However, one systematic review on recovery found that Family Drug Treatment Courts rarely focused upon life domain outcomes such as employment, social relationships, and health (Wittouck et al., 2013), and another highlighted the need for participants to have access to housing, employment, and mental health services (Boles et al., 2007). Also, drug related recidivism is associated with completion of a drug treatment court program (Mitchell et al., 2012). However, one Australian study indicated that there were much lower completion rates of Aboriginal and Torres Strait Islander clients in the Northern Territory's illicit drug court diversion program when compared to non-Indigenous clients (Rsavy et al., 2011), which may have been related to access to services or perceived lack of availability of culturally safe services.

Another broader issue has been the way in which, historically, crime prevention has been treated separately from Indigenous affairs and failed to confront the issue of high incarceration rates for 
Indigenous people. In the 1980s, an interest in crime prevention led to the establishment of separate crime prevention agencies across Australia. However, in some states of Australia, policing agencies have since absorbed crime prevention agencies (Clancey et al., 2016). Crime prevention has been narrowly focused upon neighbourhood and environmental design initiatives such as Crime Prevention Through Environmental Design, often delivered through local governments (Clancey et al., 2016), without addressing fundamental issues related to the effects of colonisation and relative disadvantage among Indigenous people. Thus, crime prevention policies and structures have historically been a "separate stream" from Indigenous affairs and justice sector policies and structures.

Additionally, whilst there has been a move away from state-centric crime prevention approaches towards partnership approaches with communities, Australian crime prevention strategies have failed to respond to the complex and diverse needs of Aboriginal and Torres Strait Islander communities in remote areas (Georg \& Manning, 2019). They have failed to address community safety as defined and understood by these communities, and expansion of the concept of community safety is required to address the complex range of problems contributing to it (Georg \& Manning, 2019). Processes to better enable community-based understandings of issues to be addressed through policy are required.

Moran (2016) also argued that different elements of policy contradict one another, and we see such contradictions in Victorian justice sector policy where there is both emphasis on reducing Indigenous incarceration rates and high and increased investment in prisons (Millar \& Vedelago, 2019). This suggests that not only are whole of government policy processes (such as Health in All Policies) required, but also that cross-sectoral accountability mechanisms and evaluation that considers primary and secondary prevention will be beneficial in the future. This should be in the broader context of more fundamental change, such as the introduction of genuine partnership approaches through treaties.

High incarceration rates are an ongoing effect of colonisation, and efforts towards Indigenous selfdetermination are required. Whilst a treaty has been proposed between the state of Victoria and its Aboriginal and Torres Strait Islander communities, this is yet to be developed. Notably, an interviewee within our study recognised that control over justice sector "resources and outcomes" was still aspirational. Nationally, a First Nations Voice to Parliament is being advocated for through the Uluru Statement from the Heart. Establishing such a representative body will be an important part of decolonising governance in Australia and will be important in achieving reductions in incarceration rates for Aboriginal and Torres Strait Islander peoples.

\section{Conclusion}

Victoria is an Australian jurisdiction that provides a good model of policies and partnerships between government and Aboriginal and Torres Strait Islander communities, and of intersectoral policy, in alignment with "strengthening community action" and "healthy public policy" actions in the Ottawa Charter. Such policies and their associated structures enabled the voice of local Aboriginal and Torres Strait Islander communities in decision-making processes and helped prevent situations that have arisen in other jurisdictions, such as poor conditions experienced by youth in detention found in the Northern Territory (Australian Government, 2017). The partnership approach taken by Victoria, through Aboriginal Justice Agreements and associated initiatives such as Koori Caucus and Koori Courts (which enable Aboriginal and Torres Strait Islander communities to have a role in justice sector decision- 
making processes) provide a good example for other countries with Indigenous Peoples. However, these policies, processes, and activities have not yet resulted in a reduction in reoffending and recidivism for Victorian Aboriginal and Torres Strait Islander communities. A greater focus on equity and primary crime prevention, over secondary and tertiary crime prevention is required, along with secondary (e.g., justice reinvestment) and tertiary strategies better tailored to Aboriginal and Torres Strait Islander communities and integrated with other areas of Indigenous affairs. A Health in All Policies approach with accountability mechanisms that include commitment and accountability from key sectors such as the health, child wellbeing and protection, education, housing, and justice sectors is required.

Internationally, there is great potential for health promotion sector knowledge and skills to be utilised within primary and secondary crime prevention activities, for example, through community development within justice reinvestment, child wellbeing, or domestic and family violence strategies.

If we are to prevent crime, one specific precursor is a shift away from public spending on prisons towards health and social programs. Greater investment in child wellbeing, parenting, health, education, housing, employment, and welfare strategies to prevent the conditions that lead to incarceration is a prerequisite for change and a reduction in incarceration rates for Aboriginal and Torres Strait Islander communities across Australia. Moreover, a change in Aboriginal and Torres Strait Islander incarceration rates is unlikely to be achieved whilst the legacy of colonialism in policies persists. This legacy is only likely to be reduced when countries that were formed on the basis of an invasion of Indigenous Peoples' lands are able to conclude a treaty with Indigenous Peoples and ensure a political voice, which involves real control and empowerment and leads to a fairer distribution of resources.

\section{References}

Alcorn, G. (2018, October 2). Law and order auction: How crime came to dominate Victoria's election. The Guardian Australia. https://www.theguardian.com/australia-news/2018/oct/03/law-andorder-auction-crime-victoria-election

Attorney-General's Department. (2013). Evaluation of Indigenous justice programs: Project B, offender support and reintegration. Final report. Australian Government. https://trove.nla.gov.au/work/ $\underline{191112511}$

Australian Bureau of Statistics. (2018). Prisoners in Australia, 2018 (ABS Catalogue No. 4517.0). https://www.abs.gov.au/ausstats/abs@.nsf/mf/4517.0

Australian Bureau of Statistics. (2019). Corrective services, Australia, March Quarter 2019(ABS Catalogue No.4512.0).https://www.abs.gov.au/ausstats/abs@.nsf/mf/4512.0

Australian Government. (2017). Royal Commission into the Detention and Protection of Children in the Northern Territory (Final report tabled November 17, 2017). https://www.royalcommission.gov.au/royal-commission-detention-and-protection-childrennorthern-territory 
Australian Government. (2020). Closing the Gap report 2020. https://ctgreport.niaa.gov.au/ sites/default/files/pdf/closing-the-gap-report-2020.pdf

Australian Law Reform Commission. (2017). Pathways to justice: Inquiry into the incarceration rate of Aboriginal and Torres Strait Islander Peoples (ALRC Report No. 133). https://www.alrc.gov.au/publication/pathways-to-justice-inquiry-into-the-incarceration-rateof-aboriginal-and-torres-strait-islander-peoples-alrc-report-133/

Baum, F. (2008). The new public health ( $3^{\text {rd }}$ ed.). Oxford University Press.

Baum, F. (2015). The new public health ( $4^{\text {th }}$ ed.). Oxford University Press.

Baum, F., Delany-Crowe, T., Fisher, M., MacDougall, C., Harris, P., McDermott, D., \& Marinova, D. (2018). Qualitative protocol for understanding the contribution of Australian policy in the urban planning, justice, energy and environment sectors to promoting health and health equity. BMJ Open, 8 (e025358). https://doi.org/10.1136/bmjopen-2018-025358

Baumann, L. C., \& Ylinen, A. (2013). Prevention: Primary, secondary, tertiary. In M. D. Gellman (Ed.), Encyclopedia of behavioral medicine (pp. 1738-1740). https://doi.org/10.1007/978-3-03039903-0 135

Boles, S., Young, N., Moore, T., \& DiPirro-Beard, S. (2007). The Sacramento Dependency Drug Court: Development and outcomes. Child Maltreatment, 12(2), 161-171. https://doi.org/ $\underline{10.1177 / 1077559507300643}$

Bondurant, S. R., Lindo, J. M., \& Swensen, I. D. (2016). Substance abuse treatment centers and local crime. Institute for the Study of Labor. http://ftp.iza.org/dp10208.pdf

Brantingham, P. J., \& Faust, F. L. (1976). A conceptual model of crime prevention. Crime and Delinquency, 22(3), 284-296. https://doi.org/10.1177/001112877602200302

Brown, D. (2010). The limited benefit of prison in controlling crime. Current Issues in Criminal Justice, 22(1), 137-148. https://doi.org/10.1080/10345329.2010.12035873

Carson, B., Dunbar, T., Chenhall, R. D., \& Bailie, R. (2007). Social determinants of Indigenous health. Allen and Unwin.

Clancey, G., Fisher, D. \& Yeung, N. (2016). A recent history of Australian crime prevention. Crime Prevention and Community Safety, 18, 309-328. https://doi.org/10.1057/s41300-016-0001-4

Corbin, J., \& Strauss, A. (2008). Basics of qualitative research. Sage Publications.

Cunneen, C., \& Tauri, J. (2018). Indigenous criminology. In A. Brisman, E. Carrabine, \& N. South, (Eds.), The Routledge companion to criminological theory and concepts (pp. 306-310). Routledge. 
Davis, M. (2019). Family is culture. Review report 2019. Independent Review of Aboriginal Children and Young People in Out of Home Care. https://www.familyisculture.nsw.gov.au/ data/assets/pdf_file/0011/726329/Family-Is-Culture-Review-Report.pdf

Dodson, P., Wootten, H., O’Dea, D., Wyvill, L., \& Johnston, E. (1991). Royal Commission into Aboriginal Deaths in Custody: Final report. Australian Government.

Dudgeon, P., Milroy, H., \& Walker, R. (2014). Working together: Aboriginal and Torres Strait Islander mental health and wellbeing principles and practice. https://www.telethonkids.org.au/ globalassets/media/documents/aboriginal-health/working-together-second-edition/workingtogether-aboriginal-and-wellbeing-2014.pdf

Ellsberg, M., Arango, D. J., Morton, M., Gennari, F., Kiplesund, S., Contreras, M., \& Watts, C. (2015). Prevention of violence against women and girls: What does the evidence say? The Lancet, 385(9977), 1555-1566. https://doi.org/10.1016/S0140-6736(14)61703-7

Empowered Communities. (2015). Empowered Communities: Empowered peoples design report. Wunan Foundation Inc.

Evans Cuellar, A., McReynolds, L. S., \& Wasserman, G. A. (2006). A cure for crime: Can mental health treatment diversion reduce crime among youth? Journal of Policy Analysis and Management 25(1), 197-214. https://doi.org/10.1002/pam.20162

Evans, M. (2018). Justice reinvestment: Literature and practice review. Southgate Institute for Health, Society and Equity, Flinders University.

Finizio, A. (2018). Aboriginal justice: The true cost of Aboriginal incarceration-the case for justice reinvestment. Bulletin (Law Society of South Australia), 40(4), 22-23.

First International Conference on Health Promotion. (1986). Ottawa Charter for Health Promotion. World Health Organization.

García, J. L., Heckman, J. J., \& Ziff, A. L. (2019). Early childhood education and crime. Infant Mental Health Journal, 40 (1), 141-151. https://doi.org/10.1002/imhj.21759

Georg, S., \& Manning, M. (2019). Safety in Indigenous communities: Identifying gaps and opportunities in Australian crime prevention policy. Policy Studies. https://doi.org/ $\underline{10.1080 / 01442872.2019 .1606902}$

Greenberg Quinlan Rosner Research. (2018). The evolving landscape of crime and incarceration. https://storage.googleapis.com/vera-web-assets/inline-downloads/iob-poll-resultssummary.pdf

Knaus, C. (2017, December 28). Prisons at breaking point but Australia is still addicted to incarceration. The Guardian. https://www.theguardian.com/australia-news/2017/dec/29/prisons-atbreaking-point-but-australia-is-still-addicted-to-incarceration 
KPMG. (2018). Maranguka Justice Reinvestment Project: Impact assessment. Just Reinvest, NSW. http://www.justreinvest.org.au/wp-content/uploads/2018/11/Maranguka-JusticeReinvestment-Project-KPMG-Impact-Assessment-FINAL-REPORT.pdf

Leigh, A. (2019). The second convict age: Explaining the return of mass imprisonment in Australia. http://andrewleigh.org/pdf/SecondConvictAge.pdf

Leppo, K., Ollila, E., Peña, S., Wismar, M., \& Cook, S. (Eds.). (2013). Health in all policies: Seizing opportunities, implementing policies. Ministry of Social Affairs and Health, Finland.

Liamputtong, P., \& Ezzy, D. (2006). Qualitative research methods (2 $2^{\text {nd }}$ ed.). Oxford University Press.

Mackean, T., Fisher, M., George, E., Friel, S. \& Baum, F. (2019). Improving implementation of Closing the Gap policy. Lowitja Institute Indigenous Health and Wellbeing Conference.

Maschi, T., Gibson, S., Zgoba, K. M., \& Morgen, K. (2011). Trauma and life event stressors among young and older adult prisoners. Journal of Correctional Health Care, 17(2), 160-172. https://doi.org/10.1177/1078345810396682

Millar, R., \& Vedelago, C. (2019, June 27). Prisons are booming as Victoria pays for its 'tough on crime' stance. The Age. https://www.theage.com.au/national/victoria/prisons-are-booming-asvictoria-pays-for-its-tough-on-crime-stance-20190627-p5220f.html

Mitchell, O., Wilson, D. B., Eggers, A., \& MacKenzie, D. L. (2012). Assessing the effectiveness of drug courts on recidivism: A meta-analytic review of traditional and non-traditional drug courts. Journal of Criminal Justice, 40, 60-71. https://doi.org/10.1016/j.jcrimjus.2011.11.009

Moran, M. (2016). Serious Whitefella stuff: When solutions became the problem in Indigenous affairs. Melbourne University Press.

Oxley, R. (2019, May 31). Victoria's high rate of Indigenous incarceration is a systemic problem. Sydney Morning Herald. https://www.smh.com.au/national/victoria-s-high-rate-of-indigenousincarceration-is-a-systemic-problem-20190531-p51t5a.html

Reeve, R., \& Bradford, W. (2014). Aboriginal disadvantage in major cities of New South Wales: Evidence for holistic policy approaches. The Australian Economic Review, 47(2), 199-217. https://doi.org/10.1111/1467-8462.12061

Rsavy, P., Cunningham, T., \& O’Reilly-Martinez, R. (2011). Preliminary analysis of the Northern Territory's illicit drug court diversion program highlights the need to examine lower program completion rates for Indigenous clients. Drug and Alcohol Review, 30, 671-676. https://doi.org/10.1111/j.1465-3362.2010.00275.x

Shaffer, D. K. (2011). Looking inside the black box of drug courts: A meta-analytic review. Justice Quarterly, 28(3), 493-521. https://doi.org/10.1080/07418825.2010.525222 
Shapiro, C. J., Prinz, R. J., \& Sanders, M. R. (2011). Facilitators and barriers to implementation of an evidence-based parenting intervention to prevent child maltreatment: The Triple P-Positive Parenting Program. Child Maltreatment, 17(1), 86-95. https://doi.org/10.1177/ $\underline{1077559511424774}$

Sherwood J. (2013). Colonisation - It's bad for your health: The context of Aboriginal health. Contemporary Nurse, 46(1), 28-40. https://doi.org/10.5172/conu.2013.46.1.28

Solar, O., \& Irwin, A. (2010). A conceptual framework for action on the social determinants of health. Social Determinants of Health Discussion Paper 2 (Policy and Practice). World Health Organization.

State of Victoria. (2019). Aboriginal over-representation in the justice system. https://www.aboriginaljustice.vic.gov.au/the-agreement/aboriginal-over-representation-in-thejustice-system

Temple, J. A., \& Reynolds, A. J. (2007). Benefits and costs of investments in preschool education: Evidence from the Child-Parent Centers and related programs. Economics of Education Review, 26(1), 126-144. https://doi.org/10.1016/j.econedurev.2005.11.004

Thalia, A. (2017, June 6). FactCheck Q and A: Are Indigenous Australians the most incarcerated people on Earth?'The Conversation. https://theconversation.com/factcheck-qanda-are-indigenousaustralians-the-most-incarcerated-people-on-earth-78528

The Sentencing Project. (2019). Fact sheet: Trends in US corrections. https://sentencingproject.org/ wp-content/uploads/2016/01/Trends-in-US-Corrections.pdf

Thomas, D. P., Briggs, V., Anderson, I.P. \& Cunningham, J. (2008). The social determinants of being an Indigenous non-smoker. Australian and New Zealand Journal of Public Health, 32(2), 110-116. https://doi.org/10.1111/j.1753-6405.2008.00185.x

Tucker, S. B., \& Cadora, E. (2003). Justice reinvestment. Open Society Institute. https://www.opensocietyfoundations.org/uploads/f44e9fba-e56c-4adf-b686b0cc95de442a/ideas reinvestment.pdf

United Nations Office on Drugs and Crime (UNODC) and World Health Organization (WHO) Europe. (2013). Good governance for prison health in the 21st century: A policy brief on the organization of prison health. https://www.euro.who.int/_data/assets/pdf file/0017/ 231506/Good-governance-for-prison-health-in-the-21st-century.pdf

Victorian Government. (2011). Victorian Government Aboriginal Inclusion Framework. http://library.bsl.org.au/jspui/bitstream/1/6704/1/Samms_Aboriginal_Inclusion_Framewor k Jan_2011.pdf 
Victorian Government. (2012). Mingu Gadhaba: Beginning together-Koori Inclusion Action Plan. https://www.justice.vic.gov.au/about-the-department/mingu-gadhaba-beginning-togetherkoori-inclusion-action-plan

Victorian Government. (2013). Victorian Aboriginal Justice Agreement Phase 3 (AJA3): A partnership between the Victorian Government and Koori community. https://files.aboriginaljustice. vic.gov.au/2021-02/Victorian\%20Aboriginal\%20Justice\%20Agreement\%20Phase\%203.pdf

Victorian Government. (2017). Yarrwul Loitjba Yapaneyepuk-Walk the talk together: Koori Inclusion Action Plan. https://www.justice.vic.gov.au/sites/default/files/embridge cache/ emshare/original/public/2020/06/4e/421381b0a/koori_inclusion_action_plan_20172020.pdf

Victorian Government. (2018a). Burra Lotjpa Dunguludja: Victorian Aboriginal Justice AgreementPhase 4. https://www.aboriginaljustice.vic.gov.au/

Victorian Government. (2018b). Victorian Aboriginal Affairs Framework 2012-2018: Building for the future: A plan for 'Closing the Gap' in Victoria by 2031. https://healthwest.org.au/wpcontent/uploads/2015/02/vic_aboriginal_affairs_framework_2013 2018.pdf

Wittouck, C., Dekkers, A., De Ruyver, B., Vanderplasschen, W., \& Vander Laenen, F. (2013). The impact of drug treatment courts on recovery: A systematic review. The Scientific World Journal, 2013. https://doi.org/10.1155/2013/493679

World Health Organization (WHO). (1986). Ottawa Charter for Health Promotion. Presented at the First International Conference on Health Promotion, Ottawa, ON, Canada. https://www.who.int/healthpromotion/conferences/previous/ottawa/en/

World Health Organization (WHO). (2014). Health for the world's adolescents: A second chance in the second decade. https://www.who.int/maternal_child_adolescent/documents/seconddecade/en/

World Health Organization (WHO) Regional Office for Europe. (2003). WHO Moscow Declaration on Prison Health as Part of Public Health. https://www.euro.who.int/_data/assets/ pdf file/0007/98971/E94242.pdf

World Health Organization (WHO) Regional Office for Europe. (2019). Health in prisons - fact sheets for 38 European countries. http://www.euro.who.int/en/health-topics/healthdeterminants/prisons-and-health/publications/2019/health-in-prisons-fact-sheets-for-38european-countries-2019 